\title{
Bisphosphonate-induced femoral fragility fractures: What do we know?
}

REVIEW

This article was published in the following Dove Press journal:

Orthopedic Research and Reviews

30 March 2010

Number of times this article has been viewed

\author{
Arkan S Sayed-Noor ${ }^{1,2}$ \\ Bakir K Kadum' \\ Göran O Sjödén ${ }^{1,2}$ \\ 'Department of Orthopaedic \\ Surgery, Sundsvall Hospital, Sundsvall, \\ Sweden; ${ }^{2}$ Department of Surgical and \\ Perioperative Sciences, Norrlands \\ University Hospital, Umeå, Sweden
}

Correspondence: Arkan S Sayed-Noor Department of Surgical and Perioperative Sciences, Norrlands University Hospital, 90185 Umeå, Sweden

Tel +46739688466

Fax +46 6018175I

Email arkansam@hotmail.com

\begin{abstract}
Bisphosphonates (BPs), in particular alendronate, are the cornerstone of treatment for postmenopausal osteoporosis. The efficacy and safety of these drugs are well documented in the literature. However, increasing numbers of reports show a possible association between long-term treatment with BPs and the occurrence of characteristic femoral fragility fractures. In this review article, we discuss the existing reports in regard to the natural history and management of these fractures. Orthopedic surgeons and other specialists dealing with patients on BP therapy should be aware of this possible association because patients with BP-induced femoral fragility fractures warrant prompt surgical management.
\end{abstract}

Keywords: bisphosphonate, alendronate, osteoporosis, fragility fractures, microdamage, bone turnover

\section{Introduction}

Osteoporosis is a major public health problem with a significant economic burden for society. ${ }^{1-4}$ The main clinical manifestaions of osteoporosis are low-energy fractures of the proximal femur, vertebrae, and distal radius. Nearly two million osteoporotic fractures occur annually in the US at an estimated cost of over $\$ 17$ billion. ${ }^{5,6}$ Most of the affected patients are elderly postmenopausal women with serious comorbidities, such as cardiovascular and renal disease, which probably contributes to the increased mortality among these patients. ${ }^{7,8}$ For those who survive, only a certain percentage regain their prefracture functional status. ${ }^{2}$ As the population ages, the incidence of these fractures is expected to triple by the year $2040 .{ }^{9,10}$

\section{Treating osteoporosis with bisphosphonates}

The treatment of osteoporosis has been revolutionized during the last 20 years. However, osteoporosis is still underdiagnosed and undertreated worldwide. ${ }^{11-13}$ At this time the cornerstone of osteoporosis treatment is BPs. These antiresorptive agents are indicated for prevention and treatment of osteoporotic fractures in patients at high risk, ie, those with bone mineral density (BMD) less than -2.5 at the femoral neck, age $\geq 50$ years, female gender, and previous low-energy fractures. ${ }^{14}$

Four BPs have been approved for the treatment of postmenopausal osteoporosis: alendronate (oral daily or once weekly) was the first to be approved by the FDA in 1995; ibandronate (oral once monthly or intravenous injection every three months); risedronate (oral; once daily, once weekly, or two consecutive days per month); and zoledronate (intravenous infusion, once yearly). ${ }^{15}$ 
Although BPs are excreted by the kidneys, the amount remaining in the body may attach to the osteoid tissue for decades. ${ }^{16}$ Osteoclasts that resorb BP-containing bone undergo apoptosis as a result of inhibition of farnesyl diphosphate synthase, an enzyme in the mevalonate pathway that is important in the maintenance of the cytoskeleton and for cell survival. ${ }^{17}$ The presence of BPs on inactive bone surfaces provides a reservoir of drug that can inhibit future generations of osteoclasts. This affinity for bone (and therefore the half-life) varies among different types of BPs and is the greatest, in order, for zoledronate, alendronate, ibandronate and risedronate. ${ }^{18} \mathrm{Via}$ this immediate and delayed osteoclast suppression, BPs inhibit bone turnover, giving rise to increased BMD and subsequently to lower risk of osteoporotic fractures.

As with other antiresorptive agents, BPs have side effects that can give rise to poor tolerance by patients, eg, upper gastrointestinal complaints (abdominal pain, dyspepsia, altered bowel motion), influenza-like symptoms (headache and musculoskeletal pain), and renal toxicity. Osteonecrosis of the jaw has also been reported as an adverse effect of BPs, especially in tumor patients treated with high intravenous doses of BPs. ${ }^{19,20}$ However, BPs are generally considered to be well tolerated by patients. ${ }^{21-23}$

\section{Efficacy of bisphosphonates}

The efficacy of BPs has been extensively studied, confirmed, and reported in the literature. However, many of these reports have lacked the statistical power needed to detect any differences in comparison with controls. ${ }^{24}$ For most of the published trials, risk reduction in morphometric vertebral fractures was used as the primary endpoint and reliably evaluated with dual-energy X-ray absorptiometry (DEXA). ${ }^{25-29}$ The incidence of hip fractures as the primary endpoint was seldom used, ${ }^{30,31}$ owing to the lower incidence of hip fractures compared with vertebral fractures, and thus requiring larger patient cohorts to detect significant risk reduction. ${ }^{32}$ Secondary endpoints have included BMD at the proximal femur, and bone resorption and formation markers, such as urinary cross-linked N-telopeptide of Type I collagen (NTX). The efficacy of BPs was shown to be equivalent regardless of the type and administration route used..$^{33-38}$

\section{Duration of treatment with bisphosphonates}

There is still debate in the literature about the optimal duration of treatment with BPs for osteoporosis. Concerns have been raised about the accumulative effects of these drugs in bone, owing to their long half-life. Moreover, randomized trials demonstrating the benefit of continuing BP use for more than five years (apart from improving BMD in the lumbar spine and hip) are lacking. The available data suggest that discontinuation of alendronate treatment after five years has no negative effect on fracture risk, evaluated as all clinical vertebral and nonvertebral fractures measured by radiographs. ${ }^{39,40}$ An exception is a group of women at very high risk for vertebral fractures and those with a femoral neck T-score on DEXA measurement of less than -2.5 after five years of alendronate. ${ }^{39,40}$ These patients do benefit from continuing BPs for more than five years. Furthermore, Curtis et $\mathrm{al}^{41}$ found that discontinuation of alendronate after three years of use was not associated with an increased risk of hip fractures during the next year compared with those who continued with treatment.

\section{Bisphosphonate-induced femoral fragility fractures}

We conducted a search of PubMed (US National Library of Medicine and National Institutes of Health) for full text articles in English on fragility farctures occurring in association with BP therapy. A manual reference check of all retrieved papers was performed to supplement the electronic searches and to identify any additional potentially relevant studies.

The potent antiresorptive effect of BPs on bone metabolism has been a concern since the very early use of these drugs in clinical practice. Flora et $\mathrm{al}^{42,43}$ studied the effect of different doses of etidronate on dogs and found that high doses of this drug given subcutaneously were associated with spontaneous fractures of the thoracic spinous processes, ribs, and pelvis. Further studies by Hirano et $\mathrm{al}^{44}$ investigated the biomechanics, histomorphology, and microdamage in affected bone. They found disturbance of bone biomechanical properties with suppression of bone turnover. The authors concluded that the increment in the rate of spontaneous fractures was the result of excessive formation of unmineralized bone. In 2005, Odvina et $\mathrm{al}^{45}$ reported nine patients who had been treated with alendronate for 3-8 years and sustained nonspinal fragility fractures. Some of these patients experienced delayed union. Histomorphometric analysis of affected bone showed severe suppression of bone turnover (SSBT) resembling adynamic bone disease. These SSBT changes included reduction in thickness and volume of osteoid tissue, reduced osteoblastic/osteoclastic surfaces, and diminished bone matrix. The authors suspected that long-term alendronate therapy with resulting SSBT might 
impair healing of the accumulated microdamage, leading to fragility fractures. Their recommendation was to increase awareness and monitoring when prescribing these drugs for a long time. Since that report, numerous studies have been published recording an association between longterm BP therapy (mainly with alendronate) and low-energy fractures of the subtrochanteric and shaft regions of the femur (Tables 1 and 2). Affected patients in these reports were classically postmenopausal women on alendronate therapy for more than five years. Some of these patients were on other medications such as corticosteroids. The causative trauma was a low-energy fall, eg, on the ground from a standing height or less, a gentle hit, or a twisting force. Plain X-rays showed a characteristic picture consisting of a transverse or short oblique fracture line, lateral cortical thickening, and medial spiking (Figure 1). On the contralateral femur, lateral cortical thickening was noticed in many of these patients and was considered to be the early stage leading to a complete fracture later on. During this early stage, patients may present with prodromal pain in the hip/thigh region for months before the occurrence of fragility fractures. Bone scan may show increased uptake at the site of the lesion.

Healing complications such as delayed union was not uncommon in these patients (Table 2). Involvement of both femoral bones and disturbed healing suggested that the causative pathology was generalized and not restricted to one location. Occurrence of fragility fractures at the subtrochanteric and shaft regions of the femur is probably the result of the increased bending forces applied on these parts of the bone, as described by Pauwels. ${ }^{61}$

The exact pathophysiology underlying these fragility fractures is still unknown. The finding of SSBT in these patients might suggest that the potent inhibitory effect of BPs on osteoclasts may lead to secondary inhibition of osteoblastic and osteocytic activities, rendering the bone adynamic and inactive. In such instances, the ability of the bone to repair microdamage may diminish or disappear. ${ }^{62}$ Furthermore, the deposition of minerals (or secondary mineralization) will continue despite SSBT. ${ }^{63,64}$ This will fill bone cavities, increasing their density and gradually making them brittle.

Table I Summary of the published data in the literature reporting the association between long-term bisphosphonate therapy and femoral fragility fractures

\begin{tabular}{|c|c|c|c|c|}
\hline Study & Study design & Number of fractures & Type of fracture & Type of bisphosphonate \\
\hline Odvina et $\mathrm{a}^{45}$ & Retrospective case series & 9 & $\begin{array}{l}\text { Sacrum, ribs, ischium, pubis, } \\
\text { femoral shaft }\end{array}$ & Alendronate \\
\hline Schneider ${ }^{46}$ & Case report & 1 & Femoral shaft & Alendronate \\
\hline Goh et $\mathrm{al}^{47}$ & Retrospective case series & 9 & Subtrochanteric & Alendronate \\
\hline Cheung et $\mathrm{al}^{48}$ & Case report & 1 & Femoral shaft & Alendronate \\
\hline Kwek et al ${ }^{49}$ & Retrospective case series & 17 & Subtrochanteric & Alendronate \\
\hline Neviasar et $\mathrm{al}^{50}$ & Retrospective case-control & 19 & $\begin{array}{l}\text { Subtrochanteric and femoral } \\
\text { shaft }\end{array}$ & Alendronate \\
\hline Sayed-Noor and Sjöden ${ }^{51}$ & Case report & 1 & Subtrochanteric & Alendronate \\
\hline Visekrune et al ${ }^{52}$ & Case report & 5 & Subtrochanteric & Alendronate \\
\hline Sayed-Noor and Sjöden ${ }^{53}$ & Case report & 2 & $\begin{array}{l}\text { Subtrochanteric and } \\
\text { peri-prosthetic femoral shaft }\end{array}$ & Alendronate \\
\hline Lenart et al ${ }^{54,55}$ & Retrospective case-control & 15 & $\begin{array}{l}\text { Subtrochanteric and femoral } \\
\text { shaft }\end{array}$ & Alendronate \\
\hline Wernecke et al ${ }^{56}$ & Case report & 2 & Subtrochanteric & $\begin{array}{l}\text { Zoledronic acid } \\
\text { and pamidronate }\end{array}$ \\
\hline Odvina et al ${ }^{57}$ & Retrospective & 13 & $\begin{array}{l}\text { I I femur (shaft, } \\
\text { subtrochanteric), I tibia, } \\
\text { I humerus }\end{array}$ & $\begin{array}{l}\text { Alendronate }(n=10) \text {, } \\
\text { Risedronate }(n=3)\end{array}$ \\
\hline Schiller and Aspenberg ${ }^{58}$ & Retrospective & 5 & Femoral shaft & Alendronate \\
\hline Edwards et $\mathrm{a}^{59}$ & Case report & 2 & $\begin{array}{l}\text { Sequential bilateral femoral } \\
\text { shaft }\end{array}$ & Alendronate \\
\hline Cermak et a ${ }^{60}$ & Case report & 5 & $\begin{array}{l}\text { Subtrochanteric and femoral } \\
\text { shaft }\end{array}$ & Alendronate \\
\hline
\end{tabular}


Table 2 Summary of the published data in the literature reporting the association between long-term bisphosphonate therapy and femoral fragility fractures

\begin{tabular}{|c|c|c|c|}
\hline Study & Treatment duration (mean) & Other manifestations & Fracture outcome \\
\hline Odvina et $\mathrm{a}^{45}$ & 5.4 years & $\mathrm{N} / \mathrm{A}$ & Delayed union \\
\hline Schneider ${ }^{46}$ & 7 years & $\begin{array}{l}\text { Prodromal pain } \\
\text { Cortical thickening on the } \\
\text { contralateral side }\end{array}$ & Delayed union \\
\hline Goh et a $\left.\right|^{47}$ & 4.2 years & $\begin{array}{l}\text { Prodromal pain } \\
\text { Cortical thickening on the } \\
\text { contralateral side }\end{array}$ & $\mathrm{N} / \mathrm{A}$ \\
\hline Cheung et $\mathrm{al}^{48}$ & 10 years & Previous contralateral fracture & Normal union \\
\hline Kwek et a ${ }^{49}$ & 4.8 years & $\begin{array}{l}\text { Prodromal pain } \\
\text { Cortical thickening on the } \\
\text { contralateral side }\end{array}$ & N/A \\
\hline Neviasar et al ${ }^{50}$ & 6.9 years & $\mathrm{N} / \mathrm{A}$ & $N / A$ \\
\hline Sayed-Noor and Sjöden ${ }^{51}$ & 7 years & $\begin{array}{l}\text { Prodromal pain } \\
\text { Cortical thickening on the } \\
\text { contralateral side }\end{array}$ & Delayed union \\
\hline Visekrune et $\mathrm{a}^{52}$ & $\begin{array}{l}5 \text { years }(n=2) \\
10 \text { years }(n=3)\end{array}$ & Prodromal pain & $\begin{array}{l}\text { Delayed union, nonunion } \\
\text { healing after teriparatide } \\
\text { therapy }\end{array}$ \\
\hline Sayed-Noor and Sjöden ${ }^{53}$ & 8.5 years & $\begin{array}{l}\text { Prodromal pain } \\
\text { Cortical thickening on the } \\
\text { contralateral sidea }\end{array}$ & Delayed union \\
\hline Lenart et $\mathrm{a}^{54,55}$ & $\begin{array}{l}7.3 \pm 1.8 \text { years }(n=10) \\
2.8 \pm 1.3 \text { years }(n=5)\end{array}$ & $\begin{array}{l}\text { Prodromal pain } \\
\text { Cortical thickening on the } \\
\text { contralateral side }\end{array}$ & N/A \\
\hline Wernecke et $\mathrm{a}^{56}$ & 9 years & $\begin{array}{l}\text { Prodromal pain } \\
\text { Cortical thickening on the } \\
\text { contralateral side }\end{array}$ & Delayed union \\
\hline Odvina et $\mathrm{al}^{57}$ & $7.3 \pm 3$ years & $\begin{array}{l}\text { Cortical thickening on the } \\
\text { contralateral side }\end{array}$ & Delayed union \\
\hline Schiller and Aspenberg ${ }^{58}$ & 5.8 years & $\mathrm{N} / \mathrm{A}$ & N/A \\
\hline Edwards et $\mathrm{a}^{59}$ & 6 years & $\begin{array}{l}\text { Prodromal pain } \\
\text { Cortical thickening on the } \\
\text { contralateral side }\end{array}$ & N/A \\
\hline Cermak et $\mathrm{al}^{60}$ & 8.5 years & $\begin{array}{l}\text { Prodromal pain } \\
\text { Cortical thickening on the } \\
\text { contralateral side }\end{array}$ & Delayed union $(n=1)$ \\
\hline
\end{tabular}

Abbreviation: N/A, not available.

Currey ${ }^{65}$ reported that bone with high mineral density can give high Young modulus of bone elasticity but a low grade of fracture toughness.

Another explanation of these fragility fractures was discussed by Visekruna et al. ${ }^{52}$ Some sort of individual BP sensitivity in patients with physiologically vulnerable osteoclasts was suggested by these authors. Additionally, Allen et al ${ }^{66}$ showed that BPs alter trabecular bone collagen cross-linking (both enzymatic and nonenzymatic) and isomerization (an index of collagen maturity). This alteration can possibly give rise to bone brittleness in the same manner as in aging, osteoporosis, and diabetes. ${ }^{67}$ On the other hand,
Aspenberg ${ }^{68}$ mentioned that BP-induced fragility fractures might affect a subset of patients with a rare bone abnormality or uncommon form of osteoporosis where bone turnover is reduced instead of the common osteoporosis form with a hypermetabolic state. The dose of BP in relation to the patient's age and weight might be another predisposing factor, although this has not been studied.

\section{Report of a typical case}

An 81-year-old woman presented in February 2009 with acute severe pain in her right hip region with inability to bear weight. This complaint started three days earlier when 


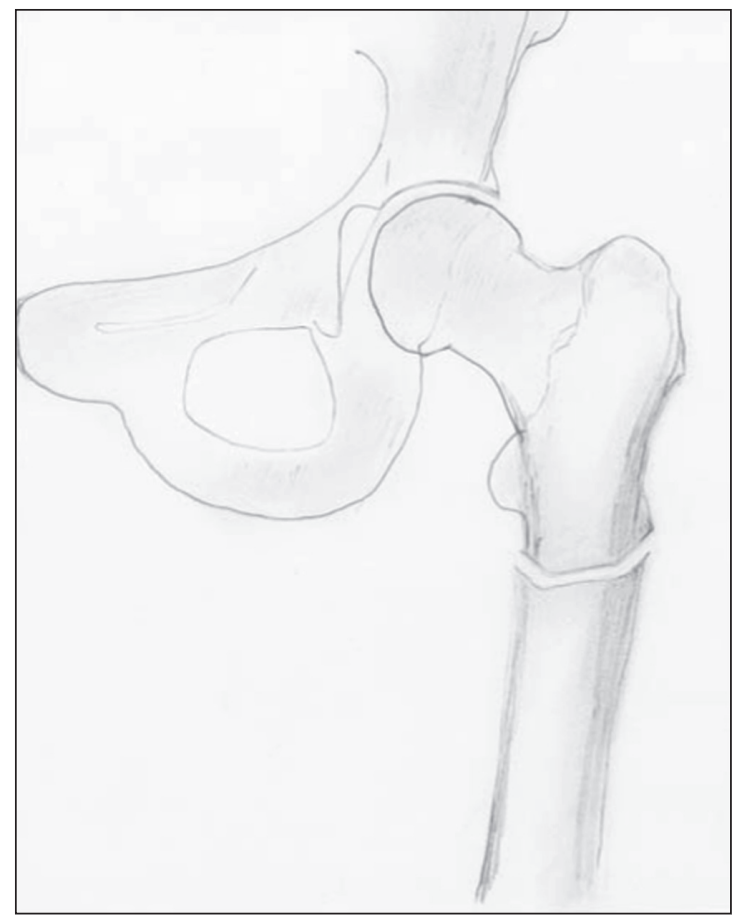

Figure I The characteristic appearance of bisphosphonate-induced femoral fragility fractures. The lateral cortex is thickened; the fracture line is transverse or short oblique with medial spiking. Look for changes in the contralateral femur, eg, thickening of the lateral cortex.

the patient was climbing stairs. History taking revealed that the patient had been on alendronate therapy (70 $\mathrm{mg}$ weekly) for the last nine years. No other drugs were taken. She had complained of right groin/thigh pain 3-4 months prior to presentation. Plain X-ray showed an undisplaced transverse subtrochanteric femoral fracture with thickening of the lateral cortex at the site of the fracture (Figures $2 \mathrm{a}$ and $2 \mathrm{~b}$ ). Hematologic investigations (complete blood pictures, electrolytes, liver and renal function tests, and thyroid hormones) showed no abnormalities.

The patient was operated on with placement of a long gamma nail. Alendronate therapy was stopped while calcium and vitamin therapy was continued. Five months postoperatively, the patient experienced minimal clinical improvement with no evidence of radiological healing. Nine months postoperatively, the patient could bear weight without limitation and the radiographs showed that the fracture gap was completely filled with callus (Figures $3 \mathrm{a}$ and $3 \mathrm{~b}$ ).

\section{Management of a bisphosphonate- induced femoral fragility fracture}

The fracture is managed operatively with nailing or plating according to the type of the fracture and the preference of the surgeon. Not uncommonly, complications such as delayed or nonunion may occur and, therefore, suitable information should be given to the patient regarding this. If delayed union seems to develop, stimulation of fracture healing by removing the distal locking screw(s) and encouraging excessive weight bearing may be needed. The authors' practise is to stop BP therapy, allowing continued calcium and vitamin D therapy. This may allow new bone formation by newly formed osteocytes. BMD is measured using DEXA scan. If this measurement reveals a $\mathrm{T}$-score $\leq-2.5$, treatment with teriparatide (recombinant human parathyroid hormone) is considered (20 $\mu \mathrm{g}$ given daily by subcutaneous injection) because there has been increasing evidence that this medication may reverse bone microdamage accumulation in postmenopausal women previously treated with $\mathrm{BPs}^{69}$ and increase bone formation rate. ${ }^{70}$ However, the appropriate duration of treatment with teriparatide is still uncertain. In patients with $\mathrm{T}$-score $>-2.5$ on DEXA measurement, who are not on corticosteroid therapy and have no increased risk for vertebral fractures, a BP drug holiday can be a suitable choice. In this case, annual DEXA measurements with or without bone resorption marker measurements (such as urinary TNX) should be undertaken. If these measurements show deterioration of BMD or if the patient develops another osteoporotic fracture, reintroduction of BP therapy or treatment with teriparatide should be considered.

There is still debate about the management of lateral cortical thickening in patients on long term BP therapy who present with hip/thigh pain. The present evidence ${ }^{53-60}$ suggests that treating these patients conservatively is likely to be unsuccessful. The authors recommend therefore stopping BP therapy and prophylactic nailing of these fractures because of the underlying pathophysiology, ie, the inability of defective bone to repair microfractures.

\section{Conclusion}

Despite the great success achieved by using BPs in osteoporotic patients during the last two decades, there remains a group of patients who may develop femoral fragility fractures secondary to SSBT caused by prolonged BP use, mainly with alendronate. The number of these cases is still relatively small but will probably increase in the future owing to the large number of patients treated with these drugs. It is therefore important to reserve continuation of BP therapy for more than five years for selected cases. Furthermore, clinicians should be aware of the association 


\section{A}

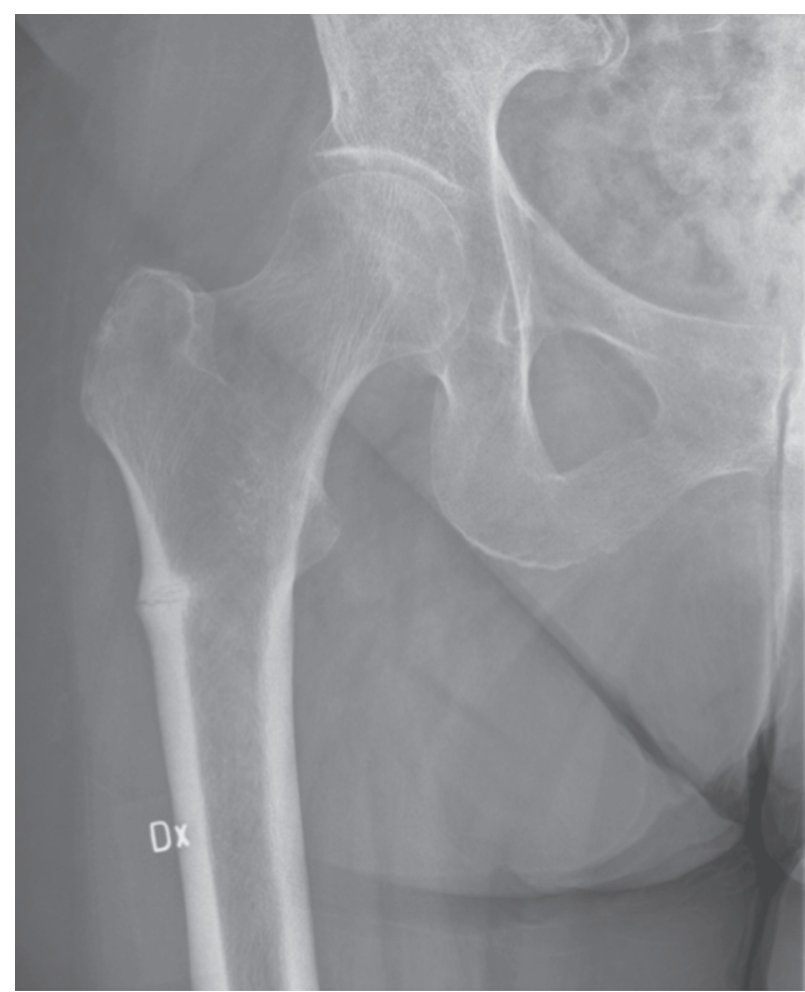

B

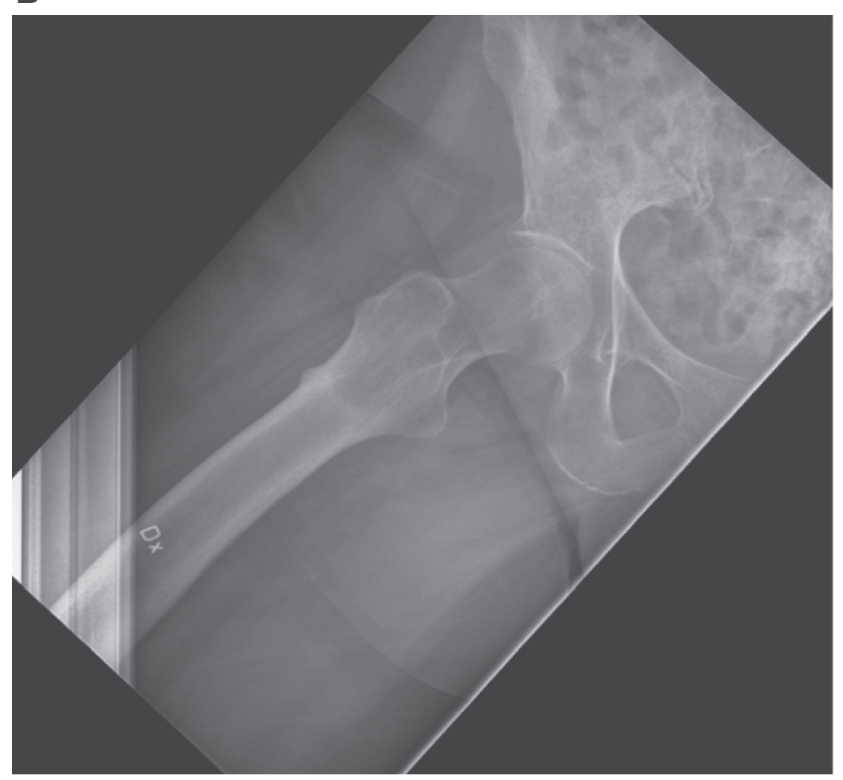

Figures 2 A and B Anteroposterior and lateral radiographic views of the hip joint showing an undisplaced subtrochanteic fracture (appeared mainly as subtrochanteric sclerosis on the lateral view). Note the lateral cortical thickening at the site of the fracture.

between long-term BP therapy and femoral fragility fractures. In patients with early changes, such as prodromal hip/thigh pain and lateral cortical thickness, stopping BP therapy and prophylactic nailing should be considered. In patients with femoral fragility fractures, healing disturbances are

\section{A}

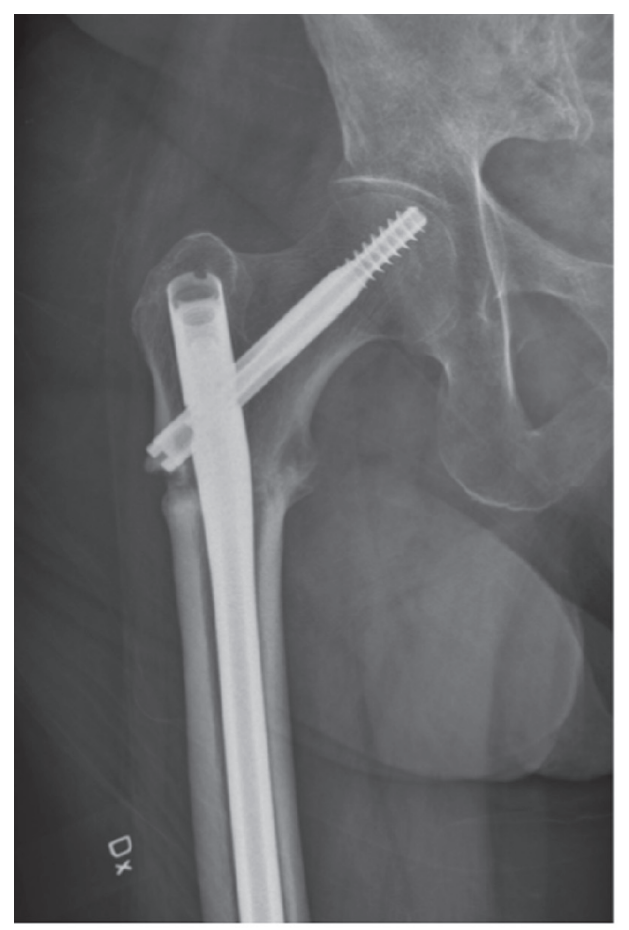

B

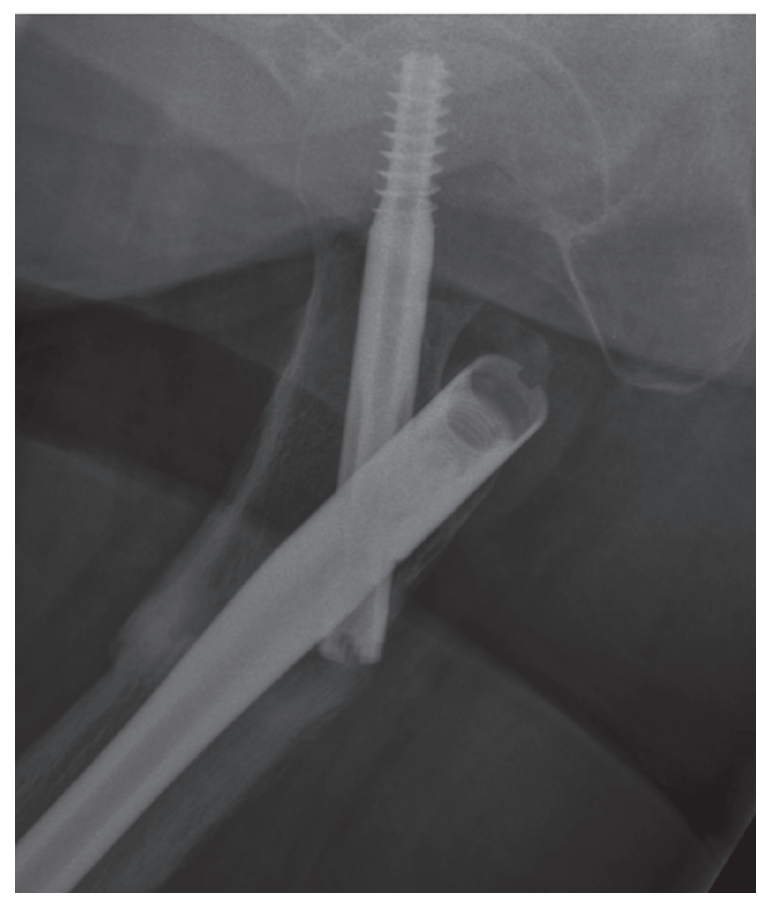

Figures 3 A and B Radiographs taken nine months postoperatively. The fracture is now healed with callus filling the fracture gap.

not uncommon, and should be anticipated and treated accordingly. If continuation of antiresorptive therapy is indicated despite the occurrence of femoral fragility fractures, teriparatide represents a promising alternative to BPs because it reduces microdamage accumulation caused by SSBT. 


\section{Disclosures}

The authors report no conflicts of interest in this work.

\section{References}

1. Lewinnek GE, Kelsey J, White AA, et al. The significance and a comparative analysis of the epidemiology of hip fractures. Clin Orthop. 1980;152:35-43.

2. Sernbo I, Johnell O. Consequences of a hip fracture: A prospective study over 1 year. Osteoporos Int. 1993;3:148-153.

3. Johnell O, Kanis J. Epidemiology of osteoporotic fractures. Osteoporos Int. 2005;16 Suppl 2:S3-S7.

4. Carlos F, Clark P, Maciel H, et al. Direct costs of osteoporosis and hip fracture: An analysis for the Mexican Social Insurance Health Care System. Salud Publica Mex. 2009;21 Suppl 1:S108-S113.

5. Johnell O, Kanis JA. An estimate of the worldwide prevalence and disability associated with osteoporotic fractures. Osteoporos Int. 2006;17:1726-1733.

6. Burge R, Dawson-Hughes B, Solomon DH, et al. Incidence and economic burden of osteoporosis-related fractures in the United States, 2005-2025. J Bone Miner Res. 2007;22:465-475.

7. Center JR, Nguyen TV, Schneider D, et al. Mortality after all major types of osteoporotic fracture in men and women: An observational study. Lancet. 1999;353:878-882.

8. Cooper C, Atkinson EJ, Jacobsen SJ, et al. Population-based study of survival after osteoporotic fractures. Am J Epidemiol. 1993;137(9): 1001-1005.

9. Schneider EL, Guralnik JM. The aging of America: Impact on health care costs. JAMA. 1990;263:2335-2340.

10. Riggs BL, Melton III LJ. The worldwide problem of osteoporosis: Insights afforded by epidemiology. Bone. 1995;17(Suppl): 505S-511S.

11. Gehlbach SH, Avrunin JS, Puleo E, Spaeth R. Fracture risk and antiresorptive medication use in older women in the USA. Osteoporos Int. 2007;18(6):805-810.

12. Häussler B, Gothe H, Göl D, et al. Epidemiology, treatment and costs of osteoporosis in Germany - the Bone EVA Study. Osteoporos Int 2007;18(1):77-84

13. Vestergaard P, Rejnmark L, Mosekilde L. Osteoporosis is markedly underdiagnosed: A nationwide study from Denmark. Osteoporos Int. 2005;16(2):134-141

14. Kanis JA, Johnell O. Requirements for DXA for the management of osteoporosis in Europe. Osteoporos Int. 2005;16(3):229-238.

15. Lewiecki EM. Intravenous zoledronic acid for the treatment of osteoporosis. Curr Osteoporos Rep. 2008;6(1):17-23.

16. Fleisch H. Bisphosphonates: Mechanisms of action. Endocr Rev. 1998;19(1):80-100.

17. Reid IR. Bisphosphonates. Skeletal Radiol. 2007;36(8):711-714.

18. Russell RG, Watts NB, Ebetino FH, et al. Mechanisms of action of bisphosphonates: Similarities and differences and their potential influence on clinical efficacy. Osteoporos Int. 2008;19(6): 733-759.

19. Khan AA, Sándor GK, Dore E, et al. Bisphosphonate associated osteonecrosis of the jaw. Canadian Taskforce on Osteonecrosis of the Jaw. J Rheumatol. 2009;36(3):478-490.

20. Khosla S, Burr D, Cauley J, et al. Bisphosphonate-associated osteonecrosis of the jaw: Report of a task force of the American Society for Bone and Mineral Research. American Society for Bone and Mineral Research. J Bone Miner Res. 2007;22(10):1479-1491.

21. Ross JR, Saunders Y, Edmonds PM, et al. A systematic review of the role of bisphosphonates in metastatic disease. Health Technol Assess. 2004;8(4):1-176.

22. Yan Y, Wang W, Zhu H, et al. The efficacy and tolerability of once-weekly alendronate $70 \mathrm{mg}$ on bone mineral density and bone turnover markers in postmenopausal Chinese women with osteoporosis. $J$ Bone Miner Metab. 2009;27(4):471-478.
23. Cadarette SM, Katz JN, Brookhart MA, et al. Comparative gastrointestinal safety of weekly oral bisphosphonates. Osteoporos Int. 2009;20(10):1735-1747.

24. Seeman E. To stop or not to stop, that is the question. Osteoporos Int. 2009;20(2):187-195.

25. Black DM, Cummings SR, Karpf DB, et al. Randomised trial of effect of alendronate on risk of fracture in women with existing vertebral fractures. Fracture Intervention Trial Research Group. Lancet. 1996;7;348(9041):1535-1541.

26. Harris ST, Watts NB, Genant HK, et al. Effects of risedronate treatment on vertebral and nonvertebral fractures in women with postmenopausal osteoporosis: A randomized controlled trial. Vertebral Efficacy With Risedronate Therapy (VERT) Study Group. JAMA. 1999;13;282(14):1344-1352.

27. Reginster J, Minne HW, Sorensen OH, et al. Randomized trial of the effects of risedronate on vertebral fractures in women with established postmenopausal osteoporosis. Vertebral Efficacy with Risedronate Therapy (VERT) Study Group. Osteoporos Int. 2000;11(1):83-91.

28. Chesnut $\mathrm{CH}$, Ettinger MP, Miller PD, et al. Ibandronate produces significant, similar antifracture efficacy in North American and European women: New clinical findings from BONE. Curr Med Res Opin. 2005;21(3):391-401.

29. Bianchi G, Sambrook P. Oral nitrogen-containing bisphosphonates: A systematic review of randomized clinical trials and vertebral fractures. Curr Med Res Opin. 2008;24(9):2669-2677.

30. McClung MR, Geusens P, Miller PD, et al. Effect of risedronate on the risk of hip fracture in elderly women. Hip Intervention Program Study Group. Hip Intervention Program Study Group. $N$ Engl $J$ Med. 2001;344(5):333-340.

31. Black DM, Delmas PD, Eastell R, et al. Once-yearly zoledronic acid for treatment of postmenopausal osteoporosis. HORIZON Pivotal Fracture Trial. N Engl J Med. 2007;356(18):1809-1822.

32. Miller PD, Ward P, Pfister T, et al. Renal tolerability of intermittent intravenous ibandronate treatment for patients with postmenopausal osteoporosis: A review. Clin Exp Rheumatol. 2008;26(6):1125-1133.

33. Schnitzer T, Bone HG, Crepaldi G, et al. Therapeutic equivalence of alendronate $70 \mathrm{mg}$ once-weekly and alendronate $10 \mathrm{mg}$ daily in the treatment of osteoporosis. Alendronate Once-Weekly Study Group. Aging (Milano). 2000;12(1):1-12.

34. Delmas PD, Benhamou CL, Man Z, et al. Monthly dosing of $75 \mathrm{mg}$ risedronate on 2 consecutive days a month: Efficacy and safety results. Osteoporos Int. 2008;19(7):1039-1045.

35. Miller PD, Roux C, Boonen S, et al. Safety and efficacy of risedronate in patients with age-related reduced renal function as estimated by the Cockcroft and Gault method: A pooled analysis of nine clinical trials. J Bone Miner Res. 2005;20(12):2105-2115.

36. Reginster JY, Adami S, Lakatos P, et al. Efficacy and tolerability of oncemonthly oral ibandronate in postmenopausal osteoporosis: 2 year results from the MOBILE study. Ann Rheum Dis. 2006;65(5):654-661.

37. Eisman JA, Civitelli R, Adami S, et al. Efficacy and tolerability of intravenous ibandronate injections in postmenopausal osteoporosis: 2-year results from the DIVA study. J Rheumatol. 2008;35(3): 488-497.

38. Bonnick S, Saag KG, Kiel DP, et al. Comparison of weekly treatment of postmenopausal osteoporosis with alendronate versus risedronate over two years. J Clin Endocrinol Metab. 2006;91(7):2631-2637.

39. Schwartz AV, Bauer DC, Cauley A, et al. Efficacy of continued Alendronate for fractures in women without prevalent vertebral fractures: The FLEX trial (Abstract 1057). Presented at the 29th annual meeting of the ASBMR, Sept 16-20, 2007.

40. Black DM, Schwartz AV, Ensrud KE, et al; (FLEX Research Group). Effects of continuing or stopping alendronate after 5 years of treatment: The Fracture Intervention Trial Long-term Extension (FLEX): A randomized trial. JAMA. 2006;296(24):2927-2938.

41. Curtis JR, Westfall AO, Cheng H, et al. Risk of hip fracture after bisphosphonate discontinuation: Implications for a drug holiday. Osteoporos Int. 2008;19(11):1613-1620. 
42. Flora L, Hassing GS, Parfitt AM, et al. Comparative skeletal effects of two bisphosphonates in dogs. Metab Bone Dis. 1980;2(Suppl):389-407.

43. Flora L, Hassing GS, Cloyd GG, et al. The long-term skeletal effects of EHDP in dogs. Metab Bone Dis Relat Res. 1981;3(4-5):289-300.

44. Hirano T, Turner CH, Forwood MR, et al. Does suppression of bone turnover impair mechanical properties by allowing microdamage accumulation? Bone. 2000;27(1):13-20.

45. Odvina CV, Zerwekh JE, Rao DS, et al. Severely suppressed bone turnover: A potential complication of alendronate therapy. J Clin Endocrinol Metab. 2005;90:1294-1301.

46. Schneider JP. Should bisphosphonates be continued indefinitely? An unusual fracture in a healthy woman on longterm alendronate. Geriatrics. 2006;61:31-33.

47. Goh SK, Yang KY, Koh JS, et al. Subtrochanteric insufficiency fractures in patients on alendronate therapy: A caution. J Bone Joint Surg Br. 2007;89:349-353.

48. Cheung RK, Leung KK, Lee KC, et al. Sequential non-traumatic femoral shaft fractures in a patient on long-term alendronate. Hong Kong Med J. 2007;13:485-489.

49. Kwek EB, Goh SK, Koh JS, et al. An emerging pattern of subtrochanteric stress fractures: A long-term complication of alendronate therapy? Injury. 2008;39:224-231.

50. Neviaser AS, Lane JM, Lenart BA, et al. Low-energy femoral shaft fractures associated with alendronate use. J Orthop Trauma. 2008;22:346-350.

51. Sayed-Noor AS, Sjoden GO. Subtrochanteric displaced insufficiency fracture after long-term alendronate therapy - a case report. Acta Orthop. 2008;79:565-567.

52. Visekruna M, Wilson D, McKiernan FE. Severely suppressed bone turnover and atypical skeletal fragility. J Clin Endocrinol Metab. 2008;93(8):2948-2952.

53. Sayed-Noor AS, Sjoden GO. Case reports: Two femoral insufficiency fractures after long-term alendronate therapy. Clin Orthop Relat Res. 2009;467(7):1921-1926.

54. Lenart BA, Neviaser AS, Lyman S, et al. Association of low-energy femoral fractures with prolonged bisphosphonate use: A case control study. Osteoporos Int. 2009;20(8):1353-1362.

55. Lenart BA, Lorich DG, Lane JM. Atypical fractures of the femoral diaphysis in postmenopausal women taking alendronate. $N$ Engl J Med. 2008;358:1304-1306

56. Wernecke G, Namdari S, Dicarlo EF, et al. Case report of spontaneous, nonspinal fractures in a multiple myeloma patient on long-term pamidronate and zoledronic acid. HSS J. 2009;5(2):204.
57. Odvina CV, Levy $\mathrm{S}$, Rao $\mathrm{S}$, et al. Unusual mid-shaft fractures during long term Bisphosphonate therapy. Clin Endocrinol (Oxf). 2009 Mar 19. [Epub ahead of print].

58. Schilcher J, Aspenberg P. Incidence of stress fractures of the femoral shaft in women treated with bisphosphonate. Acta Orthop. 2009;1:1-3.

59. Edwards MH, McCrae FC, Young-Min SA. Alendronate-related femoral diaphysis fracture - what should be done to predict and prevent subsequent fracture of the contralateral side? Osteoporos Int. 2009 June 27. [Epub ahead of print].

60. Cermak K, Shumelinsky F, Alexiou J, et al. Case reports: Subtrochanteric femoral stress fractures after prolonged alendronate therapy. Clin Orthop Relat Res. 2009 Dec 18. [Epub ahead of print].

61. Pauwels F. The significance of the structural principles of the locomotor apparatus to resist the forces applied on long bones. Anat Embryol. 1948;114:1-2. German

62. Mashiba T, Turner CH, Hirano T, et al. Effects of suppressed bone turnover by bisphosphonates on microdamage accumulation and biomechanical properties in clinically relevant skeletal sites in beagles. Bone. 2001;28(5):524-531.

63. Boivin G, Meunier PJ. Effects of bisphosphonates on matrix mineralization. J Musculoskelet Neuronal Interact. 2002;2: 538-543.

64. Zoehrer R, Roschger P, Paschalis EP, et al. Effects of 3- and 5-year treatment with risedronate on bone mineralization density distribution in triple biopsies of the iliac crest in postmenopausal women. $J$ Bone Miner Res. 2006;21:1106-1112.

65. Currey JD. Effects of differences in mineralization on the mechanical properties of bone. Philos Trans R Soc Lond B Biol Sci. 1984;304: 509-518.

66. Allen MR, Gineyts E, Leeming DJ, et al. Bisphosphonates alter trabecular bone collagen cross-linking and isomerization in beagle dog vertebra. Osteoporos Int. 2008;19(3):329-337.

67. Saito M, Marumo K. Collagen cross-links as a determinant of bone quality: A possible explanation for bone fragility in aging, osteoporosis, and diabetes mellitus. Osteoporos Int. 2010;21(2):195-214.

68. Aspenberg P. Bisphosphonate-induced fractures: Nature strikes back? Acta Orthop. 2008;79(4):459-460.

69. Dobnig H, Stepan JJ, Burr DB, et al. Teriparatide reduces bone microdamage accumulation in postmenopausal women previously treated with alendronate. J Bone Miner Res. 2009;24(12):1998-2006.

70. Jobke B, Pfeifer M, Minne HW. Teriparatide following bisphosphonates: Initial and long-term effects on microarchitecture and bone remodeling at the human iliac crest. Connect Tissue Res. 2009;50:46-54.
Orthopedic Research and Reviews

\section{Publish your work in this journal}

Orthopedic Research and Reviews is an international, peer-reviewed, open access journal that focusing on the patho-physiology of the musculoskeletal system, trauma, surgery and other corrective interventions to restore mobility and function. Advances in new technologies, materials, techniques and pharmacological agents are particularly welcome. The journal welcomes

\section{Dovepress}

original research, clinical studies, reviews \& evaluations, expert opinion and commentary, case reports and extended reports. The manuscript management system is completely online and includes a very quick and fair peer-review system, which is all easy to use. Visit http://www.dovepress. com/testimonials.php to read real quotes from published authors. 